\title{
Critical Thinking Ability Training and Classroom Teaching At the University of a Two-Way Connection
}

\author{
Wu Li \\ East China University of Political Science and Law, China 200042 \\ shealingham@163.com
}

\begin{abstract}
Keywords: Critical thinking; Two-way connection; Educational reform; University education
\end{abstract}
\begin{abstract}
In China, the current education has many problems, especially in university education. It's important to change teaching ideas, update teaching concept to cultivate a kind of critical thinking effectively to promote the students' problem awareness and analysis ability. The problem solving skills, as well as the formation of moral quality and cultural quality need to improve. At present there exist many problems in practice, however, such as teachers should also be constantly improve their own quality in order to adapt the changing social needs. This study used the author's class survey data to find the factors what the students concerned. We find knowledge is the highest factors that student evaluate. Form is the lowest factors that student evaluates, and attraction is the middle. Critical thinking ability training can be used in classroom teaching reform in Chinese university.
\end{abstract}

\section{Introduction and Summary}

Critical thinking began in the early 20th century and this concept put forward by American educator John Dewey. Critical thinking (also called thinking) is a kind of higher level thinking ability, such as Paul defines it as "in order to determine the value of things, use appropriate evaluation criteria, after thinking, make rational according to the judgment" .The cultivation of critical thinking ability has generally attention in western countries in recent decades. Since twentieth Century in the year of $60 \mathrm{~s}$ and $70 \mathrm{~s}$, according rethink to the traditional teaching methods, people start thinking about the application of critical thinking in the teaching. Many teachers have been take the important research and exploration. In China, the importance of the critical thinking ability training has been recognized, but grassroots teachers also very lack of specific training method. In China teachers input students more knowledge. The thinking ability of students, especially the critical thinking ability has not been adequate training and attention. As a teacher from east China university of politics and law, I'm responsible for teaching monetary bank in school of business. Most of my students are in their freshman year, their curiosity is very strong. This study selected 2014, 2015 undergraduate students who learning of monetary Banks in our school as the research object, I tried to take critical thinking ability training in the classroom.

\section{The Design of the Study}

It is generally believed that there are many factors that can attract the students. However, according to my research, the factors of attracting students are not on the same degree. Although we know students concerned about the course roughly, we never thought accurately get feedback from the students' learning process. For example, in the monetary banking course I taught, students have deep awareness of the importance of the course. But they don't like the pattern that I teach them without interactive. It made me realize the need to improve the teaching methods of the course. Scientific and reasonable approach is to survey the students care about the most relevant courses. So I list ten factors to let students to score, and the score range from one to five. Five points represent the most important and one point represent the least important. We put the different ten factors listed in Fig. 1. It needs to be explained these factors are conclude in my teaching work. We let the students to score of these 10 factors and we put the highest score, lowest and in the middle of the 
three factors listed in Table 1.

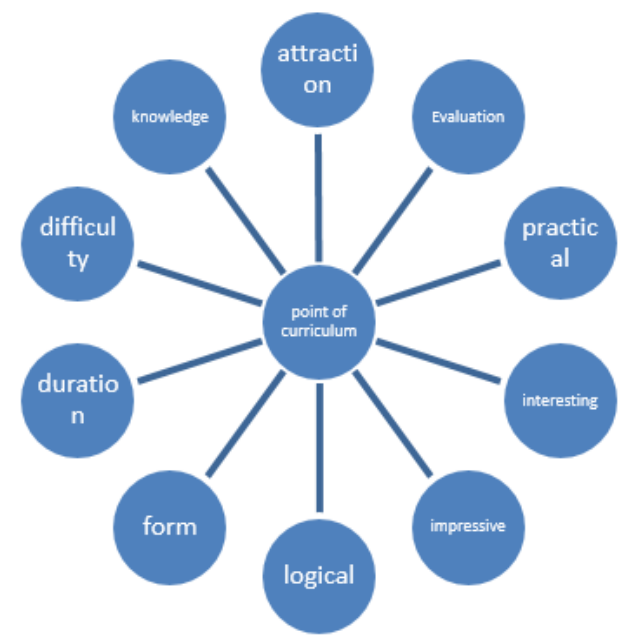

Table1. students rating investigation

\begin{tabular}{lllll}
\hline group & & Q1 & Q2 & Q3 \\
\hline 1 & mean & 3.72 & 2.93 & 4.08 \\
& $\mathrm{~N}$ & 56 & 50 & 58 \\
2 & mean & 3.55 & 2.88 & 3.91 \\
& $\mathrm{~N}$ & 82 & 80 & 77 \\
\multirow{2}{*}{ All } & mean & 3.62 & 2.90 & 3.98 \\
& $\mathrm{~N}$ & 138 & 130 & 135 \\
& & & & \\
\hline
\end{tabular}

Figure 1. Course characteristics of the students care about

These three factors are knowledge, form and attraction. We found that the number of valid answer of each question is not the same, but the difference is not big. Knowledge is the highest factors that student evaluate. Form is the lowest factors that student evaluate, and attraction is the middle. Of course, we need a scientific index to evaluate the questionnaire Cronbach indicator is a good indicator to measure the reliability, the formula is

$$
\alpha=[K /(K-1)]\left[1-\left(\sum S_{i}^{2}\right) / S_{x}^{2}\right],
$$

$\alpha$ coefficient and the relationship between the credibility as shown in Table 2.

This research completely without any pressure to students, therefore, we should think the student's answer is true. In fact, we handle all the ten questions and we found that the scores were quite concentrated, in order to better illustrate the problem we concerned, avoid too much factors interfere our study, we choose the three of them and list the final result.

Construct is a concept which according to our need to build, construct validity by means of investigating the results to verify the measurement of the concept of a certain degree to measure the concept. If the subjects on a scale score can effectively explain the psychological characteristics, this scale has good construct validity. In the process of construction scale, we have established the index system of construct validity, and therefore the questionnaire is effective.

Table 2. coefficient and credibility

\begin{tabular}{l|l}
\hline Cronbach's $\alpha$ & credibility \\
\hline 0.9 & Absolutely credible \\
$0.5-0.9$ & Very credible \\
$0.4-0.5$ & credible \\
$0.3-0.4$ & Barely credible \\
0.3 below & Not credible \\
\hline
\end{tabular}

We acquire the test scale reliability coefficient is 0.78 , it means very credible. Validity of inspection is the effectiveness of the result of the questionnaire survey, it can test whether the measurement results of the questionnaire reflect what it should reflect. Specifically, the validity of inspection must be according to their specific functions and scope of application, consider the purpose of all aspects of the information and collected the data from different angles. Commonly used validity test include content validity, structure validity, easy validity and criterion validity.

Through the questionnaire survey, we found the attention of the student about the classroom teaching. Some of the factors' ranking is different of our thinking. All of these prove the importance of the two-way connection method. Two-way connection, which is also called infiltration type class. British educator Newman had said, because the knowledge of the subject matter itself is tightly integrated, knowledge have branches connected with each other, any kind of education can penetrate the university education, in other words, the function of the professional courses are available to the recessive education, especially in humanistic curriculum, to carry on the convicted education thinking, or its values. 


\section{The Application of Critical Thinking Ability Training}

Now universities are constantly advancing and deepening innovation and entrepreneurship education which gradually becomes a trend of the education reform, and is also a highlight and focus of education in colleges and universities. However, the innovation and entrepreneurship education in our country is not optimistic at present. In fact, the United States also talking about education reform. In an effort to address the problems confronting the American education system, the Obama administration has issued structural and systematic reforms such as Race to the Top. These initiatives introduce new statistics and accountability systems to gauge what constitutes "good" teaching, both from an administrative standpoint and the perspective of teacher training programs. So critical thinking ability training can be used in classroom teaching reform in Chinese university to improve this dilemma. In view of the current education we face many problems. It's important to change teaching ideas, update teaching concept is the priority of monetary banking teaching. For a long time, our professional education system exists the phenomenon of education simplification, the so-called simplification means that specialized course teachers in specialized courses tend to focus on professional knowledge input, heavy fraction in the academic evaluation, while ignoring the cultivation of students' thinking ability. The critical approach can improve the interactions between students and teachers, better focus on the students' learning effect. Teachers should first introspect their taught course and eventually to achieve the ultimate goal of quality education, teachers need to understand that knowledge is not the amount of giving, but focus on qualitative precipitation. The main purpose of university education is not to teach students with the knowledge necessary to life, but the way to let students' to learn strategies. In other words, train the student to grasp knowledge of comprehension and understanding and practical application ability is very important. Critical thinking ability training is not an empty, and two-way connection must be reflected in the classroom teaching.

In classroom teaching, teachers should make great efforts to build learning community in the classroom. And also make the student understand that learning behavior and its social and moral development have a positive impact. Using the theory and training to batch the students have critical thinking theory, give students a positive expectation, inspire students' interest in learning, self-confidence, and the students can finally realize self motivation.

\section{References}

[1] Information on http://learning.sohu.com/20160722/n460450067.shtml

[2] Ro J. A journey from the classroom to the world of educational reform: a study of three Korean teachers' practitioner inquiry[J]. Asia Pacific Journal of Education, 2016:1-14.

[3] Fullan M G. Change forces: Probing the depths of educational reform[J]. American Journal of Education, 1994(Volume 102, Number 3).

[4] Gokhale A A. Collaborative Learning Enhances Critical Thinking[J]. 1995, 7(1).

[5] Jonassen D H. Computers in the classroom: mindtools for critical thinking[M]. Prentice-Hall, Inc. 1996.

[6] Christina Keller, Lars Cernerud. Students' Perceptions of E-learning in University Education[J]. Learning, Media and Technology, 2002, 27(1-2):55-67.

[7] Weber M. On the Purpose of a University Education[J]. Educational Philosophy and Theory, 2016, 9(2).

[8] Athiyaman A. Linking student satisfaction and service quality perceptions: the case of university education[J]. European Journal of Marketing, 1997, 31(7):528-540.

[9] Sarason, Seymour Bernard. The predictable failure of educational reform[M]. Jossey-Bass, 1991. 
[10] Information on http://www.zjedu.gov.cn/news/145138146065815895.html 